Regards sur l'économie allemande

Bulletin économique du CIRAC

116-117| 2015

Varia

\title{
Société : des pratiques culturelles en hausse
}

\section{Solène Hazouard}

\section{OpenEdition}

Journals

Édition électronique

URL : http://journals.openedition.org/rea/4829

DOI : $10.4000 /$ rea. 4829

ISSN : 1965-0787

\section{Éditeur}

CIRAC

\section{Édition imprimée}

Date de publication : 1 juillet 2015

Pagination : 72

ISSN : 1156-8992

\section{Référence électronique}

Solène Hazouard, "Société : des pratiques culturelles en hausse », Regards sur l'économie allemande [En ligne], 116-117 | juillet 2015, mis en ligne le 01 juillet 2017, consulté le 15 septembre 2020. URL http://journals.openedition.org/rea/4829

Ce document a été généré automatiquement le 15 septembre 2020.

(c) CIRAC 
Société : des pratiques culturelles en hausse

Solène Hazouard 
Les Allemands fréquentent davantage les lieux culturels

1 Les Allemands aiment de plus en plus les sorties culturelles. C'est ce qui ressort d'une étude publiée par l'institut DIW de Berlin (DIW Wochenbericht, 20/ 2015). De 1995 à 2013, la part des adultes ayant participé occasionnellement ou souvent à des activités hautement culturelles (opéra, concerts de musique classique, théâtre, expositions et musées) est passée de 52 à $58 \%$. La hausse (de 53 à $64 \%$ ) a été encore plus nette pour les activités culturelles populaires (cinéma, concerts pop, concerts de jazz, spectacles de danse et discothèques).

Les écarts régionaux sont gommés par la prise en compte de multiples facteurs, ...

$2 \mathrm{Si}$, dans les grandes villes, notamment à Berlin, la demande culturelle est supérieure à la moyenne nationale, l'écart entre la capitale et le reste du pays s'est nettement réduit depuis 1998. Les chercheurs du DIW précisent que les différences territoriales sont lissées à la fois par les caractéristiques personnelles (formation, revenus et catégorie socio-professionnelle) et les conditions spécifiques du lieu de résidence (recettes fiscales régionales et dépenses culturelles des Länder et des communes).

... parmi lesquels le niveau de revenus, qui influe sur la demande culturelle

3 Ainsi, malgré les subventions conséquentes accordées à la culture (plus de 9 milliards $€$ annuels selon les dernières données disponibles, qui datent de 2009), le facteur coût reste clivant: les personnes titulaires d'un diplôme universitaire et bénéficiant de revenus élevés ont tendance à davantage fréquenter les lieux de haute culture que les autres catégories de population. Selon la même logique, les parents les plus aisés plébiscitent à $78 \%$ l'apprentissage d'un instrument de musique pour leurs enfants, contre $53 \%$ parmi la classe moyenne et seulement $36 \%$ dans les classes sociales les moins favorisées, comme en témoignent les résultats d'un sondage réalisé par l'Institut für Demoskopie d'Allensbach et publiés en avril 2015.

\section{INDEX}

Mots-clés : Consommation, culture, étude, loisir 